\title{
The Geographical Distribution of Fresh-water Eels.
}

THERE is scarcely anything in Nature more wonderful than the facts concerning the migrations and life-histories of the fresh-water eels of Europe and America brought to light by the long and persevering researches of Dr. Johannes Schmidt. $\mathrm{He}$ has now completed a general survey of what is known concerning the distribution of all the species of the genus Anguilla. The first part of this survey, including only the Atlantic Ocean and adjacent areas, was published sixteen years ago. The memoir under notice ${ }^{1}$ is the second part and is devoted to the IndoPacific region, but it contains certain important additions to the information contained in Part I., and references to the chief general conclusions of that part.

The species of Anguilla seems as a rule to be geographical species, though in some cases two or more occur in the same locality. In the Atlantic region there are only two, $A$. vulgaris on the eastern side, $A$. rostrata on the western, the former having a larval period of three years, the latter of only one year. Dr. Schmidt tells us that in the Indo-Pacific region, at the beginning of his inquiry, the determination of species was generally uncertain, the distribution obscure, and the biology altogether unknown. Some of the uncertainty with regard to species has been remedied, but the thorough investigation of the bionomics still remains for the future.

The world distribution of the whole genus shows some curious features. In the Atlantic the contrast is between north and south. On the eastern side eels are found on all the coasts of Europe and North Africa from near the Tropic of Cancer to the White Sea, including all the Mediterranean and Black Seas and the Baltic. On the east side, the range of the American species extends from Labrador to the West Indies, and includes a short stretch of the South American coast at the mouth of the Orinoco. No eels occur on the east coast of South America south of this part, or on the west coast of Africa south of the Tropic of Cancer.

In the Pacific, on the other hand, there are no eels on the east side at all from Alaska to Tierra del Fuego, while on the west they are found, often in great abundance, from Japan along the coast of China, in the Philippines, on the northern coast of New Guinea, the east coast of Australia, in both islands of New Zealand, and in nearly all the western islands of the Pacific. From the Sandwich Islands and the Galapagos farther east they are absent.

Eels occur on most of the coasts of the Indian Ocean, except the Arabian Sea and the south-west coast of Australia. With the exception of the short extent of coast from the north of Norway to Archangel, and an unimportant occurrence in Greenland, there are no eels in the Arctic or Antarctic regions. Another curious contrast is the entire absence of these fish from the shallow sea (less than roo fm.) bounded by Siam,

${ }^{1}$ On the Distribution of Fresh-water Eels (Anguilla) throughout the World. II. Indo-Pacific Region. A Bio-geographical Investigation. By Johs. 8 me série, t. 1o, No. 4 the Malay Peninsula, Sumatra, Java, and Borneo, while they pass in very large numbers over the bank at a similar depth on which the British Islands are situated. Dr. Schmidt concludes that the eel-fry immigrating from the depths of the ocean are, in the case of the Indo-Malayan species, inferior in migratory powers to those of the Atlantic species. Eels do not migrate through shallow sea-areas in the larval stage, but only after the metamorphosis, when they have reached the elver stage.

Although eels are so abundant in individuals in temperate regions, the greater number of species belong to the tropics, and Dr. Schmidt believes that the genus originated somewhere in the equatorial Pacific, and that the species have radiated out from this centre. The most widely distributed of the tropical species seems to be $A$. mauritiana, which occurs in the islands off the east coast of Africa, in the Philippines, and in many of the islands of the Pacific. In the Philippines it reaches a large size, some specimens measuring $2 \mathrm{~m}$. in length and $46 \mathrm{~cm}$. in circumference. The oceanic larva or leptocephalus of this species was obtained and identified by Schmidt at Celebes in 1925 . The ascent of great swarms of elvers from the sea to fresh water seems to be as familiar a sight in Japan as in Europe, and to occur at about the same time of year.

Apart from Europe and North America, Japan is the only country where eel fisheries have developed to a large and important industry. In New Zealand two species have been distinguished, A. australis and $A$. aucklandi, and specimens occur up to $6 \mathrm{ft}$. in length, $20 \mathrm{in}$. in circumference, $46 \mathrm{lb}$. in weight. They are used as food only to a slight extent by the European inhabitants, but are caught and eaten in considerable numbers by the Maoris.

The memoir concludes with a section entitled "General Observations," in which the author discusses the probable life-history of $A$. japonica, and the absence of a species of eel on the eastern side of the Pacific. He considers that the Japanese eel resembles the American $A$. rostrata, having a larval period of about one year, and spawning in the region of the ocean to the south of Japan, where the temperatures at $400 \mathrm{~m}$. are higher than elsewhere in the North Pacific. He suggests that the reason for the absence of eels on the eastern side of the Pacific is the absence of a species having a larval life sufficiently prolonged to enable it to make the long migration from the same spawning region to the eastern side of that ocean, since both $A$. rostrata, the American species, and the $A$. vulgaris of Europe, have been shown by Schmidt to carry on their reproduction in the western part of the North Atlantic. This does not, however, explain the absence of eels from both the east and west shores of the South Atlantic.

Like other publications of Dr. Schmidt on his researches into the characters and bionomics of freshwater eels, this memoir shows his mastery of his subject, his command of the English language, and his skill in clear and orderly statement. J. T. C.

\section{The Construction of Regular Polygons. ${ }^{1}$}

UUST as the sequence of propositions arranged by Euclid to form the first book of his "Elements" reaches its climax in the proof of Pythagoras's theorem, so those in the three succeeding books culminate in the construction of a regular pentagon.

1 "The Scientific Construction of the Regular Heptagon with Angles Correct to Ten Seconds, derived from Two Crossed-Parallelograms of a Semi-Ellipse." By T. Alexander.
In the eyes of the Pythagorean school of Greek mathematics, the five regular solids were considered to be symbols of perfection. So one of the aims of the first four books of the "Elements "was to supply accepted reasoning that would lead to the construction of regular polygons of three, four, and five sides-the only ones which can be the faces of a regular solid.

No further advance in the theory of constructing

$$
\text { NO. 2943, VOL. I I 7] }
$$

